\title{
Columnar Cell Change of the Breast with Atypia
}

National Cancer Institute

\section{Source}

National Cancer Institute. Columnar Cell Change of the Breast with Atypia. NCI

Thesaurus. Code C54182.

A columnar cell lesion characterized by the presence of enlarged terminal ductal lobular units with dilated acini. The acini are lined by one or two layers of columnar epithelial cells. Cytologic atypia is present. 